\title{
Characterization of Acinetobacter spp. from raw goat Milk
}

\author{
Gustavo Luis de Paiva Anciens Ramos ${ }^{1}$ (D) Janaína dos Santos Nascimento ${ }^{2 *}$ (D)
}

\begin{abstract}
${ }^{1}$ Laboratório de Higiene e Microbiologia de Alimentos, Faculdade de Farmácia, Universidade Federal Fluminense (UFF), Niterói, RJ, Brasil. ${ }^{2}$ Laboratório de Microbiologia, Instituto Federal de Educação, Ciência e Tecnologia do Rio de Janeiro (IFRJ), 20270-021, Rio de Janeiro, RJ, Brasil. E-mail: janaina.nascimento@ifrj.edu.br. "Corresponding author.
\end{abstract}

ABSTRACT: Goat's milk has been suggested as an alternative to cow's milk, being a better digestible and hypoallergenic option. However, the presence of contaminating bacteria may significantly affect the safety of the product. In this research, we reported the isolation and characterization of Acinetobacter spp. isolates from raw goat milk samples purchased in the state of Rio de Janeiro, Brazil. Twenty-one samples were analyzed and ten isolates of Acinetobacter spp. were obtained. Six were identified as A. guillouiae, three as A. ursingii, and one as $A$. bereziniae. These isolates were characterized and eight showed proteolytic activity, seven showed lipolytic activity, and five isolates were able to produce both enzymes. None of the isolates was biofilm producer. However, when the production of antibiotic resistance enzymes KPC and ESBL were investigated, all isolates presented ESBL-positive phenotype, while eight (80\%) were KPC-positive. This research, therefore, demonstrated that raw goat's milk can also be a source of Acinetobacter spp., which can produce important thermostable deteriorating enzymes and may play a role of reservoirs of antibiotic resistance genes.

Key words: goat milk, Acinetobacter, deteriorating enzymes, KPC, ESBL.

Caracterização de Acinetobacter spp. isolados de leite caprino cru

RESUMO: O leite de cabra tem sido sugerido como alternativa ao leite de vaca, sendo uma opção com melhor digestibilidade e menor alergenicidade. No entanto, a presença de bactérias contaminantes pode afetar significativamente a segurança do produto. Neste trabalho, relatamos o isolamento e caracterização de Acinetobacter spp. isolados de amostras de leite cru de cabra adquiridas no Estado do Rio de Janeiro, Brasil. Vinte e uma amostras foram analisadas e dez isolados de Acinetobacter spp. foram obtidos, sendo seis identificados como A. guillouiae, três como A. ursingii e um como A. bereziniae. Estes isolados foram caracterizados e oito apresentaram atividade proteolitica, sete mostraram atividade lipolítica e cinco foram capazes de produzir ambas as enzimas. Nenhum dos isolados foi produtor de biofilme. No entanto, todos os isolados apresentaram fenótipo ESBL-positivo, enquanto oito (80\%) foram positivos para KPC. Este trabalho demonstra, portanto, que o leite de cabra cru também pode ser uma fonte de Acinetobacter spp., que podem produzir enzimas deteriorantes termoestáveis e desempenhar, também, um papel de reservatórios de genes de resistência a antibióticos.

Palavras-chave: leite caprino, Acinetobacter, enzimas deteriorantes, KPC, ESBL.

Goat milk has proven to be an effective substitute to bovine milk, due to the lower levels of $\alpha$-s1 casein, which triggers allergic reactions. It also aids better digestion due to the presence of smaller fat globules and larger quantities of medium and short chain fatty acids (VERRUCK et al., 2019). In addition, goat's milk also has a high nutritional value and tends to be an excellent culture medium for deteriorating and pathogenic micro-organisms that encompass a wide variety of gram-negative bacteria.

Little is known about the role of foods in the transmission of Acinetobacter spp., probably because there are no standard procedures to recover them from foods (CARVALHEIRA et al., 2016; AMORIM \& NASCIMENTO, 2017). However, many papers described the presence of Acinetobacter spp. in bovine raw and pasteurized milk, dairy products, and in powdered milk (NEUBECK et al., 2015; CHO et al., 2018). In this research, we reported the isolation and characterization of Acinetobacter spp. isolates from 21 samples of raw goat milk purchased directly from producers in several regions of the state of Rio de Janeiro, Brazil. Samples were collected over a period of five months.

Isolates were obtained by plating the samples on violet red agar bile glucose (VRBG) and selecting about 15 colonies per sample, from typical (pink color with halo) and atypical. Approximately 300 isolates obtained were identified by mass spectrometry (MALDI-TOF, Microflex LT, 
Bruker, United States). The VRBG agar was used because, originally, the analysis was performed for the detection of Enterobacteriaceae. However, as described by $\mathrm{CHO}$ et al. (2018), VRBG also allowed the recovery of members of the genus Acinetobacter. Microbial population reported in the raw milk samples was evaluated from 222 accurately identified isolates, being mainly composed of Pseudomonas spp. (61\%) and members of the Enterobacteriaceae family (26.6\%). However, 10 (4.5\%) of Acinetobacter spp. were also isolated from the milk samples. Six were identified as $A$. guillouiae, three as $A$. ursingii, and one as $A$. bereziniae (Table 1 ). These isolates came exclusively from four samples of raw goat milk. It is noteworthy that $A$. baumannii, an important pathogen, was not reported in any of the samples analyzed.

For the evaluation of lipolytic and proteolytic enzymes, the isolates were inoculated into milk agar [1\% skimmed milk powder $\left(\right.$ Molico $^{\circledR}$, São Paulo, Brazil), 0.5\% yeast extract (BD Biosciences, San Jose, USA), 1.5\% agar-agar (Merck)] and modified Spirit blue agar $[1 \%$ peptone (Himedia, Mumbai, India), $0.5 \%$ yeast extract (BD Biosciences, San Jose, USA), 2\% agar-agar (Merck, Sao Paulo, Brazil), and $3 \%$ lipoidal emulsion (20\% of olive oil (Borges, Tàrrega, Spain), $0.2 \%$ Tween 80 (Proquimios, Rio de Janeiro, Brazil)] at $37^{\circ} \mathrm{C}$ up to 5 days. Eight isolates showed proteolytic activity, seven showed lipolytic activity, and five isolates were able to produce both enzymes (Table 1). Proteases and lipases produced by some micro-organisms are able to resist pasteurization or UHT treatment. In milk and in other dairy products, these enzymes can lead to undesirable defects, such as bitter taste, gelling, and rancidity (MARCHAND et al., 2009; NEUBECK et al., 2015).

The biofilm-producing activity was investigated as described by FREEMAN et al. (1989), growing the isolates on Congo red agar [15 g/L nutrient agar (Merck), $37 \mathrm{~g} / \mathrm{L}$ sucrose (Pro Analysis, São Paulo, Brazil) and $0.8 \mathrm{~g} / \mathrm{L}$ Congo red (Vetec, Rio de Janeiro, Brazil)] at $37^{\circ} \mathrm{C}$ for up to 48 $\mathrm{h}$. The biofilm producing colonies appear black and may make the culture medium the same coloration, based on the production of exopolysaccharides. This method is fast, inexpensive and has good sensitivity and reproducibility, allowing rapid qualitative detection of biofilm produced by Gram-negative bacteria (HEDAYATI et al., 2014; AMORIM et al., 2018). None of the isolates; however, were observed to be a biofilm producer (Table 1); although, this characteristic has been detected in Acinetobacter spp. isolated from food (CHERIF-ANTAR et al., 2016).

Isolates of the carbapenem-resistant Acinetobacter baumannii-calcoaceticus complex were reported in infant formulas and nursing utensils in a public hospital in Rio de Janeiro (ARAÚJO et al., 2015). To investigate whether the isolates reported in this study were also capable of producing extended spectrum beta-lactamases (ESBL) and carbapenemase (KPC), the isolates were grown in the CHROMagar ${ }^{\circledR}$ KPC and CHROMagar ${ }^{\circledR}$ ESBL selective chromogenic media. Studies have reported the efficiency and sensitivity of these chromogenic media, indicating high correspondence rates compared to other methods (HAJI et al., 2012; PRABHA et al., 2016).

Table 1 - Characteristics of the Acinetobacter sp. isolates obtained from samples of raw goat's milk.

\begin{tabular}{|c|c|c|c|c|c|c|}
\hline Sample $n^{\circ}$ & Isolates & Biofilm & Protease & Lipase & $\mathrm{KPC}$ & ESBL \\
\hline 14 & Acinetobacter bereziniae & - & + & + & + & + \\
\hline 15 & Acinetobacter ursingii & - & + & - & - & + \\
\hline 17 & Acinetobacter guillouiae & - & + & - & + & + \\
\hline 17 & Acinetobacter guillouiae & - & + & + & + & + \\
\hline 17 & Acinetobacter guillouiae & - & + & - & + & + \\
\hline 17 & Acinetobacter guillouiae & - & - & + & + & + \\
\hline 17 & Acinetobacter guillouiae & - & + & + & + & + \\
\hline 17 & Acinetobacter guillouiae & - & + & + & + & + \\
\hline 20 & Acinetobacter ursingii & - & - & + & - & + \\
\hline 20 & Acinetobacter ursingii & - & + & + & + & + \\
\hline
\end{tabular}

+, positive; -, negative; ESBL, extended spectrum beta-lactamases; KPC, Klebsiella penumoniae-carbapenemase. 
The ESBL production was confirmed by double disc synergy test (DDST) on Muller-Hinton agar, as described by Drieux and coworkers (2008). The amoxicillin-clavulanic acid disk $(20 / 10 \mu \mathrm{g})$ was positioned at the center, with four $30 \mu \mathrm{g}$ disks of aztreonam, ceftazidime, ceftriaxone and cefepime placed adjacent to the central disk at a distance of 20 $\mathrm{mm}$. After incubation at $37^{\circ} \mathrm{C}$ for $18 \mathrm{~h}$, any distortion or increase in the zone towards the disc of amoxicillinclavulanic acid was considered as positive for the ESBL production.

Of the ten isolates, all presented ESBLpositive phenotype, both in CHROMagar ${ }^{\circledR}$ ESBL and in the DDST, while eight (80\%) were KPC-positive. Only 2 isolates of $A$. ursingii from two different samples of goat's milk were KPC-negative. Other studies have also detected carbapenem-resistant Acinetobacter strains from extra-hospital reservoirs such as animals, dairy products, and environmental samples (CHOI et al., 2012; POIREL et al., 2012). Our results; therefore, reinforce the conclusions of GURUNG et al. (2013) that, in order to efficiently evaluate the quality of milk, it is important to test it not only for classical foodborne pathogens but also for Acinetobacter spp., as these pathogens could pose a potential public health concern.

This research, therefore, demonstrated that raw goat's milk is also a source of Acinetobacter spp., which may even produce important thermostable deteriorating enzymes. In addition, these strains are also important reservoirs of antibiotic resistance genes, which can be transferred to other microorganisms that are a part of the goat's milk microbiota.

\section{ACKNOWLEDGEMENTS}

This work was financed by the program Prociência from the Instituto Federal de Educação, Ciência e Tecnologia do Rio de Janeiro, and in part by the Coordenação de Aperfeiçoamento de Pessoal de Nível Superior (CAPES), Brasil. JSN thanks the research productivity grant from Conselho Nacional de Desenvolvimento Científico e Tecnológico ( $\mathrm{CNPq}$ - Grant no. 301394/2015-6).

\section{DECLARATION OF CONFLICT OF INTERESTS}

The authors declare no conflict of interest. The founding sponsors had no role in the design of the study; in the collection, analyses, or interpretation of data; in the writing of the manuscript, and in the decision to publish the results.

\section{AUTHORS' CONTRIBUTION}

The authors contributed equally to the manuscript.

\section{REFERENCES}

AMORIM, A. M. B. et al. A reddish problem: Antibiotic-resistant Serratia marcescens in dairy food commercialized in Rio de Janeiro. International Food Research Journal, 25:880-883. 2018. Available from: <www.ifrj.upm.edu.my/25\%20(02)\%20 2018/(60).pdf>. Accessed: Feb. 14, 2019.

AMORIM, A. M. B., NASCIMENTO, J. S. Acinetobacter: an underrated foodborne pathogen? Journal of Infection on Developing Countries, 11(2):111-114. 2017. Available from: $<$ https://jidc.org/index.php/journal/article/view/28248670>. Accessed: Feb. 08, 2019. doi: 10.3855/jidc.8418.

ARAÚJO, B. C. et al. Multidrug-resistant Acinetobacter baumannii-calcoaceticus complex isolated from infant milk formula and utensils in a nursery in Rio de Janeiro, Brazil. Journal of Dairy Science, 98:2303-2306. 2015. Available from: <https:// www.journalofdairyscience.org/article/S0022-0302(15)00095-8/ fulltext>. Accessed: Feb. 07, 2019. doi: 10.3168/jds.2014-8825.

CARVALHEIRA, A. et al. Enrichment of Acinetobacter spp. from food samples. Food Microbiology, 55:123-127. 2016. Available from: <https://www.sciencedirect.com/science/article/ pii/S0740002015002087?via\%3Dihub>. Accessed: Feb. 07, 2019. doi: 10.1016/j.fm.2015.11.002.

CHERIF-ANTAR, A. et al. Diversity and biofilm-forming capability of bacteria recovered from stainless steel pipes of a milk-processing dairy plant. Dairy Science and Technology, 96(1):27-38. 2016. Available from: <https://link.springer.com/ article/10.1007/s13594-015-0235-4>. Accessed: Feb. 10, 2019.

CHO, G. S. et al. Diversity and antibiotic susceptibility of Acinetobacter Strains From Milk Powder Produced in Germany. Frontiers in Microbiology, 9:536. 2018. Available from: $<\mathrm{https} / /$ www.frontiersin.org/articles/10.3389/fmicb.2018.00536/full>. Accessed: Jan. 22, 2019. doi: 10.3389/fmicb.2018.00536.

CHOI, J. Y. et al. Acinetobacter species isolates from a range of environments: species survey and observations of antimicrobial resistance. Diagnostic Microbiology and Infectious Disease, 74(2):177-180. 2012. Available from: <https:/www.sciencedirect. com/science/article/abs/pii/S073288931200274X?via\%3Dihub>. Accessed: Dec. 12, 2018. doi: 10.1016/j.diagmicrobio.2012.06.023.

DRIEUX, L. et al. Phenotypic detection of extended spectrum $\beta$ lactamase production in Enterobacteriaceae: review and bench guide. Clinical Microbiology and Infection, 14: 90-103. 2008. Available from: <https://www.sciencedirect.com/science/ article/pii/S1198743X14604791>. Accessed: Jun. 30, 2019. doi: 10.1111/j.1469-0691.2007.01846.x.

GURUNG, M. et al. Prevalence and antimicrobial susceptibility of Acinetobacter from raw bulk tank milk in Korea. Journal of Dairy Science, 96(4):1997-2002. 2013. Available from: $<$ https://www.journalofdairyscience.org/article/S00220302(13)00132-X/fulltext>. Accessed: Dec. 19, 2018. doi: $10.3168 /$ jds.2012-5965

HAJI, H. B. et al. Study on prevalence of KPC producing from Klebsiella pneumoniae using Modified Hodge Test and CHROMagar in Iran. Annals of Biological Research, 3(12):56595664. 2012. Available from: <https://www.researchgate.net/ publication/237838255_A_study_on_prevalence_of_KPC_ 
producing_from_Klebsiella_pneumoniae_using_Modified_Hodge Test_and_CHROMagar_in_Iran>. Accessed: Feb. 19, 2019.

HEDAYATI S. et al. Biofilm Formation by Bacteria Isolated from Intravenous Catheters. Journal of Medical Bacteriology, 3(3):2631. 2014. Available from: <http://jmb.tums.ac.ir/index.php/jmb/ article/view/33>. Accessed: Feb. 19, 2019.

MARCHAND, S. et al. Heterogeneity of heat-resistant proteases from milk Pseudomonas species. International Journal of Food Microbiology, 133:68-77. 2009. Available from: $\quad<$ https://www.sciencedirect.com/science/article/pii/ S0168160509002529?via\%3Dihub $>$. Accessed: Dec. 21, 2018. doi: 10.1016/j.ijfoodmicro.2009.04.027.

NEUBECK, M. et al. Biodiversity of refrigerated raw milk microbiota and their enzymatic spoilage potential. International Journal of Food Microbiology, 211:57-65. 2015. Available from: <https://www.sciencedirect.com/sneubeccience/article/pii/ S0168160515300556?via\%3Dihub>. Accessed: Dec. 20, 2018. doi: 10.1016/j.ijfoodmicro.2015.07.001.
POIREL, L. et al. Carbapenemase-producing Acinetobacter spp. in cattle, France. Emerging Infectious Diseases Journal, 18(3):523. 2012. Available from: <https://www.ncbi.nlm.nih.gov/pmc/ articles/PMC3309584/>. Accessed: Jan. 16, 2019.

PRABHA, R. et al. Phenotypic detection of Extended Spectrum Beta- Lactamase producing uropathogens using DDST, PCT, Chromagar and E-test - A comparitive study. International Journal of Current Microbiology and Applied Sciences, 5(4):565-577. 2016. Available from: <https://www.researchgate. net/publication/301276597 Phenotypic detection of Extended Spectrum_Beta-_Lactamase_producing_uropathogens_using_ DDST PCT Chrom agar and E-test - A comparitive study>. Accessed: Jan. 16, 2019.

VERRUCK, S. et al. Functionality of the components from goat's milk, recent advances for functional dairy products development and its implications on human health. Journal of Functional Foods, 52:243-257. 2019. 2019. Available from: <https://www. sciencedirect.com/science/article/pii/S1756464618305930>. Accessed: Dec. 07, 2018. doi: 10.1016/j.jff.2018.11.017 . 